aneurysm, resection and replacement of the aneurysmal LAD with venous graft between the cut ends associated with triple bypass of the LAD and diagonal and marginal arteries with the mammary arteries crafted in a Y graft was undertaken. The size and site of the described aneurysm make it quite exceptional; furthermore, we believe that it is one of the largest atherosclerotic aneurysms reported in the medical literature. ${ }^{4,5}$

\section{References}

1. Koizumi J, Izumoto H, Ohsawa A, Ishibashi K, Ishihara K, Kawazoe K. Giant coronary artery aneurysm in diagonal artery; report of a case. Kyobu Geka. 2002;55:793-5.
2. Nakamura Y, Yashiro M, Oki I, Tanihara S, Ojima T, Yanagawa H. Giant coronary aneurysms due to Kawasaki disease: a case-control study. Pediatr Int. 2002;44:254-8.

3. Shrivastava V, Akowuah E, Cooper GJ. Coronary artery aneurysm with a fistulous connection to the right atrium mimicking a sinus of Valsalva aneurysm. Heart. 2003;89:E4.

4. Merchan A, Lopez-Minguez JR, Alonso F, Fernandez De La Concha J, Gonzalez R, Martinez De La Concha L. Giant left main coronary aneurysm without associated coronary lesions. Rev Esp Cardiol. 2002; 55:308-11.

5. Barettella MB, Bott-Silverman C. Coronary artery aneurysm: an unusual case report and a review of the literature. Cathet Cardiovasc Diagn. 1993;29:57-61.

\title{
Implantation of an autologously endothelialized homograft
}

\author{
Helmut Gulbins, MD, Angelika Goldemund, Antje Uhlig, Anita Pritisanac, MD, Bruno Meiser, MD, and \\ Bruno Reichart, MD, Munich, Germany
}

A

lthough cells have been shown to retain viability during cryopreservation, the luminal surface of cryopreserved homografts is normally not covered by viable endothelial cells. Therefore the surface of these grafts does not possess anticoagulatory properties. The low incidence of thromboembolic events in clinical settings could be explained by the high flow through the aortic valve and the resulting short contact times. Additionally, surviving donor cells elicit an immunologic reaction of the recipient. ${ }^{1-3}$ In experimental studies a chronic rejection of the homografts by the recipient was shown to be one major reason for graft degeneration and failure. Covering the luminal surface with autologous cells of the recipient might overcome these obstacles. This would lead to a physiologic luminal surface, resulting in an even further lowered thromboembolic risk. Additionally, the bloodstream would only come into contact with autologous cells, thus avoiding immunologic activation and subsequent rejection. We report the first, to our knowledge, clinical case of implantation of an autologously endothelialized aortic homograft. The study was approved by the local ethics committee, and the patient provided informed consent to participate.

\footnotetext{
From the Department of Cardiac Surgery, University Hospital Grosshadern, Munich, Germany.

Received for publication Feb 21, 2003; accepted for publication March 6, 2003.

Address for reprints: Helmut Gulbins, MD, Department of Cardiac Surgery, University Hospital Grosshadern, LMU Munich, D-81366, Munich, Germany (E-mail: H.Gulbins@ @hch.med.uni-muenchen.de).

J Thorac Cardiovasc Surg 2003;126:890-1

Copyright $\odot 2003$ by The American Association for Thoracic Surgery $0022-5223 / 2003 \$ 30.00+0$

doi:10.1016/S0022-5223(03)00609-3
}

\section{Clinical Summary}

A 59-year-old woman (blood group A) was referred to our hospital because of aortic valve stenosis on the basis of a bicuspid aortic valve. Preoperative examinations excluded significant coronary artery disease and other relevant concomitant diseases. Echocardiography showed an aortic valve stenosis with a calculated valvular orifice of $0.7 \mathrm{~cm}^{2}$, trivial aortic regurgitation, normal left ventricular function with mild hyper-

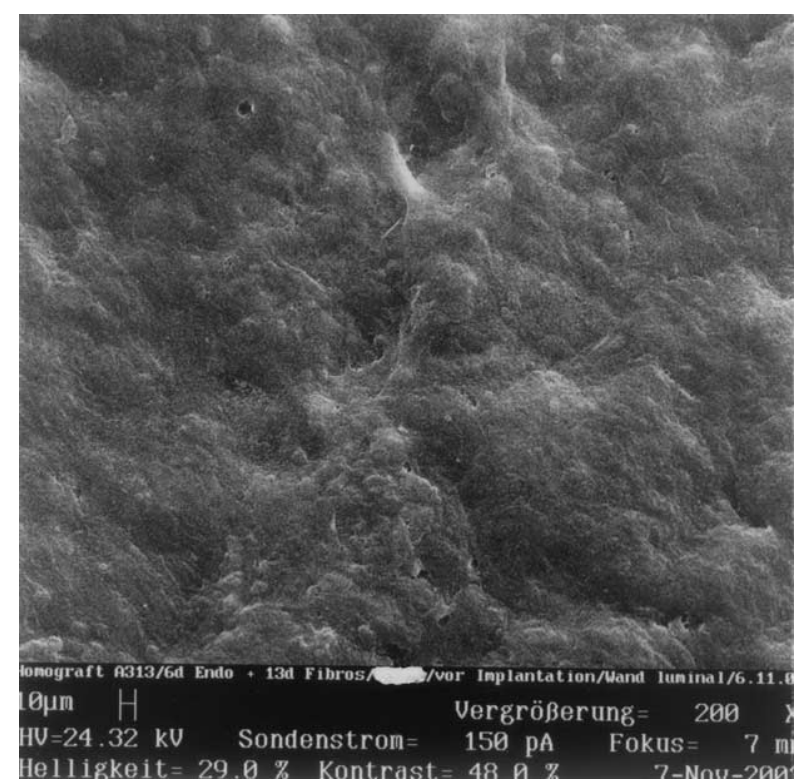

Figure 1. Scanning electron microscopic image. (Original magnification 200x.) A confluent endothelial cell layer is seen on the luminal surface. This specimen was taken directly before implantation. 


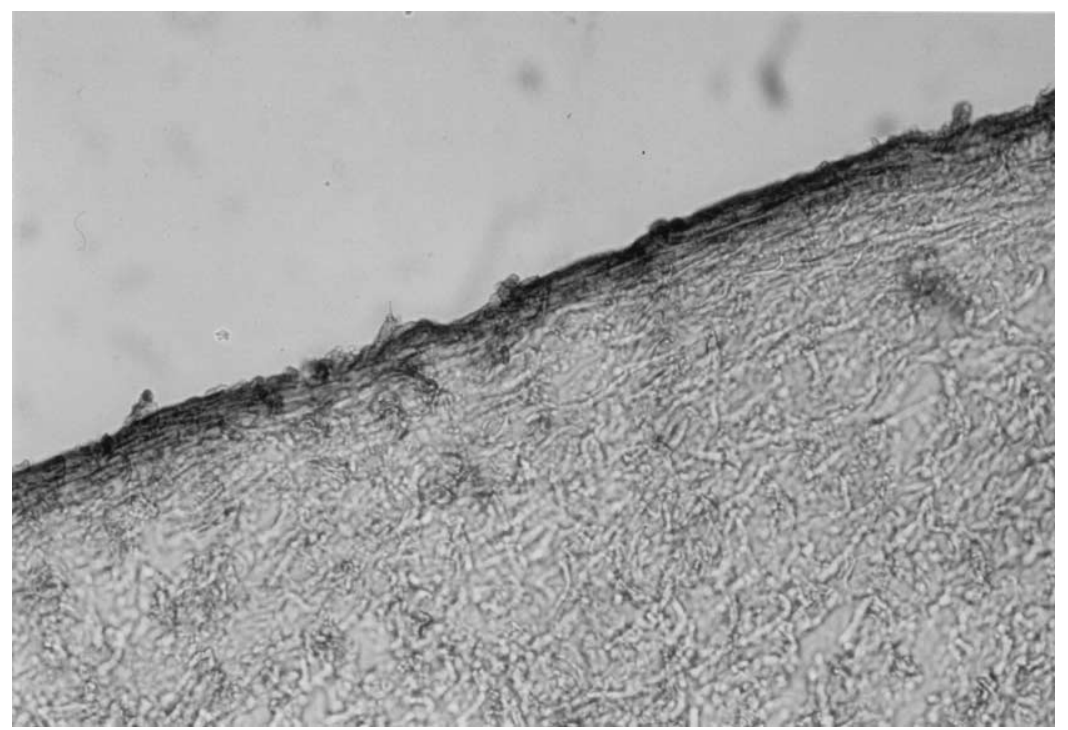

Figure 2. Immunohistochemical staining, antibody for factor VIII, peroxidase reaction. (Original magnification $20 \times$.) The figure shows a clearly positive reaction on the luminal surface, indicating a confluent layer of viable endothelial cells. The specimen was taken directly before implantation.

trophy, and a competent mitral valve. The annulus of the aortic valve was determined to be $20 \mathrm{~mm}$ by using different echocardiographic sections. One piece of the great saphenous vein $(6$ $\mathrm{cm}$ ) was harvested from the patient's left lower leg and transferred to the laboratory in endothelial cell medium (Promocell, Heidelberg). Endothelial cells and fibroblasts were harvested from this saphenous vein piece and expanded in culture. After 3 weeks, $2.7 \times 10^{7}$ fibroblasts were seeded onto a cryopreserved aortic homograft (diameter of $20 \mathrm{~mm}$, donor blood group AB). After a resting period of 7 days, a specimen was taken from the upper edge of the graft and examined under the scanning electron microscope. A confluent layer of fibroblasts was seen. Thereafter, $2.5 \times 10^{7}$ endothelial cells were seeded onto the graft. During the whole time of culturing the cells on the graft, probes of the cell medium were taken for microbiologic testing to exclude any contamination of the graft. For documentation of the successful seeding procedure, specimens were taken after the seeding and before implantation. At that time, a confluent endothelial cell layer (Figure 1) was found. Immunohistochemical staining for factor VIII and CD31 proved the cells to be viable (Figure 2). After a resting period of 6 days, the graft was implanted in the aortic position by using the miniroot technique with reimplantation of the coronary arteries. The patient had an uneventful postoperative course. The inflammatory response (C-reactive protein, interleukin 6 , and tumor necrosis factor $\alpha$ ) did not exceed that usually occurring after operations requiring extracorporal circulation. Especially in the cytoimmunologic monitoring, no activation was seen during the first 10 days after implantation. Echocardiography revealed a normal function of the implanted graft.

\section{Discussion}

Homografts were shown to be suitable for endothelial cell seeding. ${ }^{4,5}$ Lehner and colleagues ${ }^{2}$ showed that endothelialized homografts implanted in a primate model maintained their confluent cell layer over a period of 4 weeks. After implantation in human subjects, however, it was difficult to prove that the endothelial cell layer was not lost. Fischlein and colleagues ${ }^{3}$ showed evidence for an immunologic response of the recipients elicited by the implanted homografts, and Oei and coworkers ${ }^{4}$ showed that patients who received a homograft had donor-specific T-cell responses. In the presented case no evidence for an ongoing inflammatory response was found, especially that cytoimmunologic monitoring revealed no activation, which was proven to take place when homografts were implanted in a manner incompatible with the ABO blood group system. ${ }^{6}$ Although these are only indirect signs for a still confluent endothelial cell layer on the graft, the presented case shows the feasibility of implanting prostheses altered by means of tissue engineering.

\section{References}

1. Eberl T, Siedler S, Schumacher B, Zilla P, Schlaudraff K, Fasol R. Experimental in vitro endothelialization of cardiac valve leaflets. Ann Thorac Surg. 1992;53:487-92.

2. Lehner G, Fischlein T, Baretton G, Murphy JG, Reichart B. Endothelialized biological heart valves prostheses in the non-human primate model. Eur J Cardiothorac Surg. 1997;11:498-504.

3. Fischlein T, Schutz A, Haushofer M, Frey R, Uhlig A, Detter C, et al. Immunologic reaction and viability of cryopreserved homografts. Ann Thorac Surg. 1995;60(suppl 2):S122-5.

4. Oei FBS, Welters MJ, Knoop CJ, Vaessen LM, Stegmann AP, Weimar $\mathrm{W}$, et al. Circulating donor-specific cytotoxic $\mathrm{T}$ lymphocytes with high avidity for donor human leukocyte antigens in pediatric and adult cardiac allograft valved conduit recipients. Eur J Cardiothorac Surg. 2000;18:466-72.

5. Oei FBS, Welters MJ, Vaessen LM, Stegmann AP, Bogers AJ, Weimar W. Induction of cytotoxic $\mathrm{T}$ lymphocytes with destructive potential after cardiac valve homograft implantation. J Heart Valve Dis. 2000;9:761-8.

6. Smith JD, Ogino H, Hunt D, Laylor RM, Rose ML, Yacoub MH. Humoral response to human aortic valve homografts. Ann Thorac Surg. 1995;60:S127-30. 